\title{
Phase transition in copper(II) pyrovanadate
}

\author{
N SURESH RAO and O G PALANNA
}

Materials Science Research Laboratory, Department of Chemistry, St. Philomena College, Puttur 574 202, India

MS received 28 February 1992; revised 6 May 1992

\begin{abstract}
A new phase $\mathrm{Cu}_{2} \mathrm{~V}_{2} \mathrm{O}_{7}$ synthesized, exhibits phase transitions between $475^{\circ} \mathrm{C}$ and $500^{\circ} \mathrm{C}$. These phase transitions are reversible with ease in contrast to $\alpha \rightarrow \beta$ phase transition at $712^{\circ} \mathrm{C}$ of $\mathrm{Cu}_{2} \mathrm{~V}_{2} \mathrm{O}_{7}$ phase reported earlier. These phase transitions are identified by DTA technique and characterized by detailed XRD investigations at different temperatures. The crystal structures of these $\mathrm{Cu}_{2} \mathrm{~V}_{2} \mathrm{O}_{7}$ phases are related to either thort veitite $\left(\mathrm{Sc}_{2} \mathrm{Si}_{2} \mathrm{O}_{7}\right)$ type or a modification of it.
\end{abstract}

Keywords. Copper(II) pyrovanadate; phase transition; crystal structure.

\section{Introduction}

A considerable interest has been generated to study the crystal chemistry of the type $\mathrm{M}_{2} \mathrm{~V}_{2} \mathrm{O}_{7}$ where $\mathrm{M}$ is divalent cation since the structures of these types are governed by the rules based on their relative dimensions, $\mathrm{M} / \mathrm{o}$ and $\mathrm{V} / \mathrm{o}$. These compounds can be related to either thortveitite structure (Cruickshank et al 1962) (figure 1) or a modification of it. Structural studies of metal pyrovanadates show a variety of new structural modifications: thortveitite structure for $\mathrm{Mn}_{2} \mathrm{~V}_{2} \mathrm{O}_{7}$ (Dorm and Mariander 1967), $\mathrm{Cd}_{2} \mathrm{~V}_{2} \mathrm{O}_{7}$ (Calvo and $\mathrm{Au}$ 1967), $\mathrm{Cu}_{2} \mathrm{~V}_{2} \mathrm{O}_{7}$ (Ayamonino et al 1973), and related structures in $\alpha-\mathrm{Zn}_{2} \mathrm{~V}_{2} \mathrm{O}_{7}$ (Gopal and Calvo 1973; Angenault 1970), $\beta-\mathrm{Cu}_{2} \mathrm{~V}_{2} \mathrm{O}_{7}$ (Mercurio et al 1973b), $\mathrm{Mg}_{2} \mathrm{~V}_{2} \mathrm{O}_{7}$ (Gopal and Calvo 1974), $\beta-\mathrm{Sr}_{2} \mathrm{~V}_{2} \mathrm{O}_{7}$ (Baglio and Dann 1971); $\mathrm{Ca}_{2} \mathrm{~V}_{2} \mathrm{O}_{7}$ (Monelescu 1974), $\alpha-\mathrm{Cu}_{2} \mathrm{~V}_{2} \mathrm{O}_{7}$ (Mercurio et al 1973a; Calvo and Faggiani 1975) and $\mathrm{Mn}_{2} \mathrm{~V}_{2} \mathrm{O}_{7}$ (Ziolkowski and Deimbaj 1978).

The investigations of copper(II) ion in vanadates are curious ones since $\mathrm{Cu}^{2+}\left(d^{9}\right)$ could induce $\mathrm{Jahn}$ - Teller distortion of metal-oxygen polyhedra in $\mathrm{Cu}_{2} \mathrm{~V}_{2} \mathrm{O}_{7}$ lattice and also in crystal structures of the type $\mathrm{M}_{2} \mathrm{~V}_{2} \mathrm{O}_{7}$ (where $\mathrm{M}=\mathrm{Cu}^{2+}, \mathrm{Zn}^{2+}$ etc) having the crystal symmetry other than monoclinic $\mathrm{C}^{2} / \mathrm{m}$, phase transition could be predicted at higher temperatures.

The $\alpha \rightarrow \beta$ phase transition of $\mathrm{Cu}_{2} \mathrm{~V}_{2} \mathrm{O}_{7}$ was observed (Fluery et al 1969), but

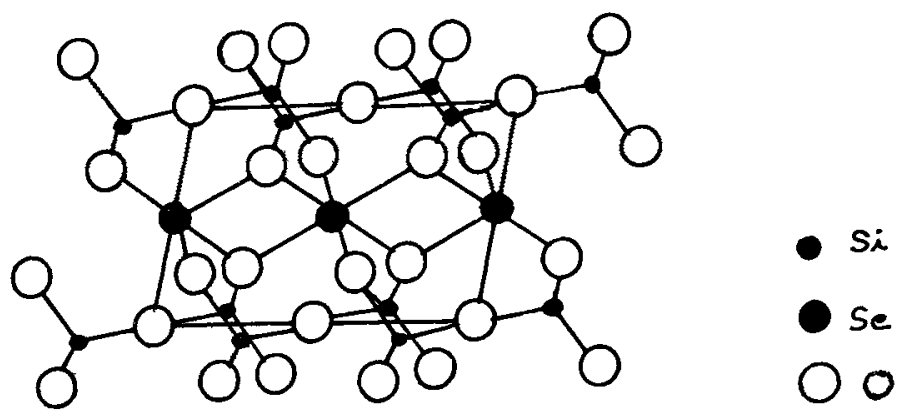

Figure 1. Structure of thortveitite $\left(\mathrm{Sc}_{2} \mathrm{Si}_{2} \mathrm{O}_{7}\right)$ projected on b-face. 
ambiguity still persists regarding the identification of structural phases in the above phase transformations at $712^{\circ} \mathrm{C}$. However, many structural types of $\mathrm{Cu}_{2} \mathrm{~V}_{2} \mathrm{O}_{7}$ related to thortveitite family were reported (Riassento 1958; ASTM card file No. 16-417), orthorhombic Fdd2 (Mercurio et al 1973a; Calvo and Faggiani 1975) and monclinic C2/m (Fluery et al 1969; Ayamonino et al 1973). Therefore, a detailed investigation of DTA and high temperature XRD characterization of $\mathrm{Cu}_{2} \mathrm{~V}_{3} \mathrm{O}_{7}$ was carried out to study the $\alpha \rightarrow \beta$ phase transition and to identify and index the possible structural modifications.

\section{Experimental}

\subsection{Preparation of $\mathrm{Cu}_{2} \mathrm{~V}_{2} \mathrm{O}_{7}$ sample}

The copper(II) pyrovanadate was synthesized by a conventional solid state technique by heating in air an intimate mixture of $2 \mathrm{CuO}: \mathrm{V}_{2} \mathrm{O}_{5}$ (both of high purity grade at $600^{\circ} \mathrm{C}$ for $24 \mathrm{~h}$ ) in a Pt crucible which was then melted in air. The sample was then annealed (10/min) slowly in air to room temperature (sample I). Another batch of $\mathrm{Cu}_{2} \mathrm{~V}_{2} \mathrm{O}_{7}$ was synthesized as above, annealed slowly to room temperature; again heated to $550^{\circ} \mathrm{C}$ for $15 \mathrm{~min}$ and quenched to liquid $\mathrm{N}_{2}$ temperature $(80 \mathrm{~K})$ (sample II).

\section{$2.2 X$-ray diffraction studies}

The $\mathrm{Cu}_{2} \mathrm{~V}_{2} \mathrm{O}_{7}$ samples synthesized above were characterized by $X$-ray powder diffraction technique using $\mathrm{CuK}_{\alpha}$ radiation $(\lambda=1.541 \mathrm{~A}, \mathrm{Ni}$ filter).

The high temperature XRD studies were made on an MRC attachment to a Philips PW 1051 diffractometer using $\mathrm{CuK}_{\alpha}$ radiation. The sample was maintained at each temperature for about $15 \mathrm{~min}$.

A Pt-Pt 13\% Rh thermocouple was used for measuring the temperature of the sample.

\subsection{Differential thermal analysis}

The differential thermal analysis (DTA) was carried out using a fabricated unit and was recorded on a strip chart recorder (sensitivity: $1 \mathrm{mV} / 10$ inches). The following conditions were maintained during DTA run of the samples: (1) sample holder $-\mathbf{P t}$ cups, reference material $-\mathrm{Al}_{2} \mathrm{O}_{3}$, heating rate $-8 / \mathrm{min}$, atmosphere-static air, standard material $-\mathrm{Na}_{2} \mathrm{Wo}_{4} 2 \mathrm{H}_{2} \mathrm{O}$.

\section{Results and discussion}

The DTA of $\mathrm{Cu}_{2} \mathrm{~V}_{2} \mathrm{O}_{7}$ (sample $\mathrm{I}$ ) phase obtained as above is shown in figure 2. The new $\mathrm{Cu}_{2} \mathrm{~V}_{2} \mathrm{O}_{7}$ phase exhibits endothermic peak at $475^{\circ} \mathrm{C}$ and a knee at $500^{\circ} \mathrm{C}$ indicating phase transformations (curve 1) (m.p. $780^{\circ} \mathrm{C}$ ). On cooling the DTA sample in air in DTA unit, two distinct exotherms (curve 2) at $485^{\circ} \mathrm{C}$ and $435^{\circ} \mathrm{C}$ were obtained showing the reversibility of the process. A lower temperature $\left(712^{\circ} \mathrm{C}\right)$ phase transition for $\mathrm{Cu}_{2} \mathrm{~V}_{2} \mathrm{O}_{7}$ has not been reported to date. The DTA run of the above sample 


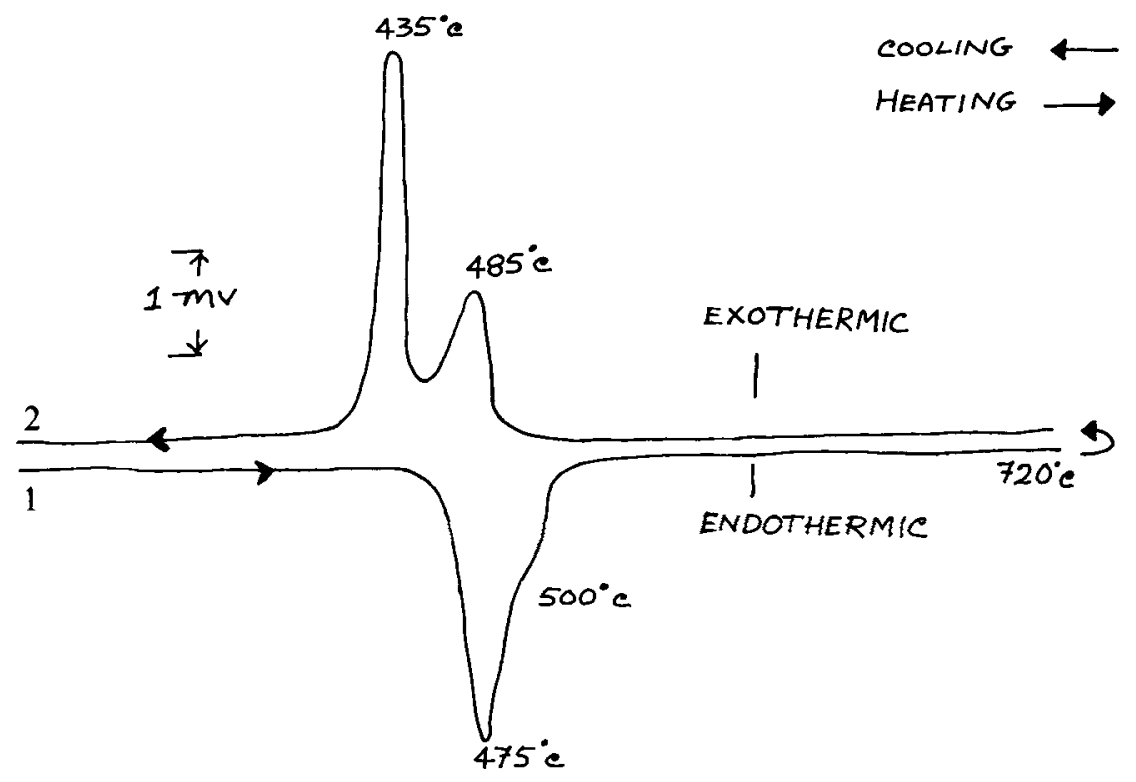

Figure 2. DTA of $\mathrm{Cu}_{2} \mathrm{~V}_{2} \mathrm{O}_{7}$ in static air (sample-I).

under a set of above conditions were repeated several times to confirm this and the DTA results were reproducible and reversible.

The sample I thus prepared was characterized by X-ray powder diffraction studies and identified as $\mathrm{Cu}_{2} \mathrm{~V}_{2} \mathrm{O}_{7}$ (Riassento 1958; ASTM card file No 16-417) (figure 3(I)) and was isostructural to $\mathrm{Cu}_{2} \mathrm{~V}_{2} \mathrm{O}_{7}$ phase obtained by Mercurio et al (1973a) and Calvo and Faggiani (1975) which they called $\alpha-\mathrm{Cu}_{2} \mathrm{~V}_{2} \mathrm{O}_{7}$. This confirms therefore that the $\alpha-\mathrm{Cu}_{2} \mathrm{~V}_{2} \mathrm{O}_{7}$ (sample I) could only be obtained from a melt of the phase obtained from $2 \mathrm{CuO}: \mathrm{V}_{2} \mathrm{O}_{5}$ by solid state reaction in air atmosphere which was as described earlier.

To confirm the predicted structural modifications at high temperature, we have quenched sample I from $550^{\circ} \mathrm{C}$ to liquid nitrogen temperature $(80 \mathrm{~K})$ to stabilize the possible high temperature modification (sample II). The XRD pattern of this $\mathrm{Cu}_{2} \mathrm{~V}_{2} \mathrm{O}_{7}$ phase is shown in figure 3 (II).

A new XRD $2 \theta$-intensity spectrum was obtained (e.g. reflections as d $\AA$ :3.60 $\AA, 3.09 \AA$ and $3.06 \AA$ ) indicating a new high temperature $\mathrm{Cu}_{2} \mathrm{~V}_{2} \mathrm{O}_{7}$ phase. The strongest intensity reflection of the phase (sample I) positioned at $3.27 \AA$ disappeared and a new strongest reflection peak appeared at $3.60 \AA$. Other peaks appeared at $3.09 \AA$, $3.06 \AA, 2 \cdot 11 \AA$, etc. Incidentally, the entire XRD $2 \theta$-intensity reflections of the high temperature form (quenched sample II) match exactly with the XRD data presented by Mercurio et al (1973b) known as $\beta-\mathrm{Cu}_{2} \mathrm{~V}_{2} \mathrm{O}_{7}$.

This new XRD $2 \theta$-intensity reflections of quenched sample of $\mathrm{Cu}_{2} \mathrm{~V}_{2} \mathrm{O}_{7}$ prompted us to reinvestigate, to trace the possible structural modifications at high temperature and to identify the phases at low and high temperatures and their structural relationship based on this biography of the sample.

The high temperature $\mathrm{X}$-ray diffractograms of the sample $\mathrm{Cu}_{2} \mathrm{~V}_{2} \mathrm{O}_{7}$ (sample I) were taken between $25^{\circ} \mathrm{C}$ and $625^{\circ} \mathrm{C}$ at an interval of about $50^{\circ} \mathrm{C}$. The X-ray diffractograms were recorded only after the sample was maintained at equilibrium temperature for 
(I) Melted and slowly cooled to R.T.

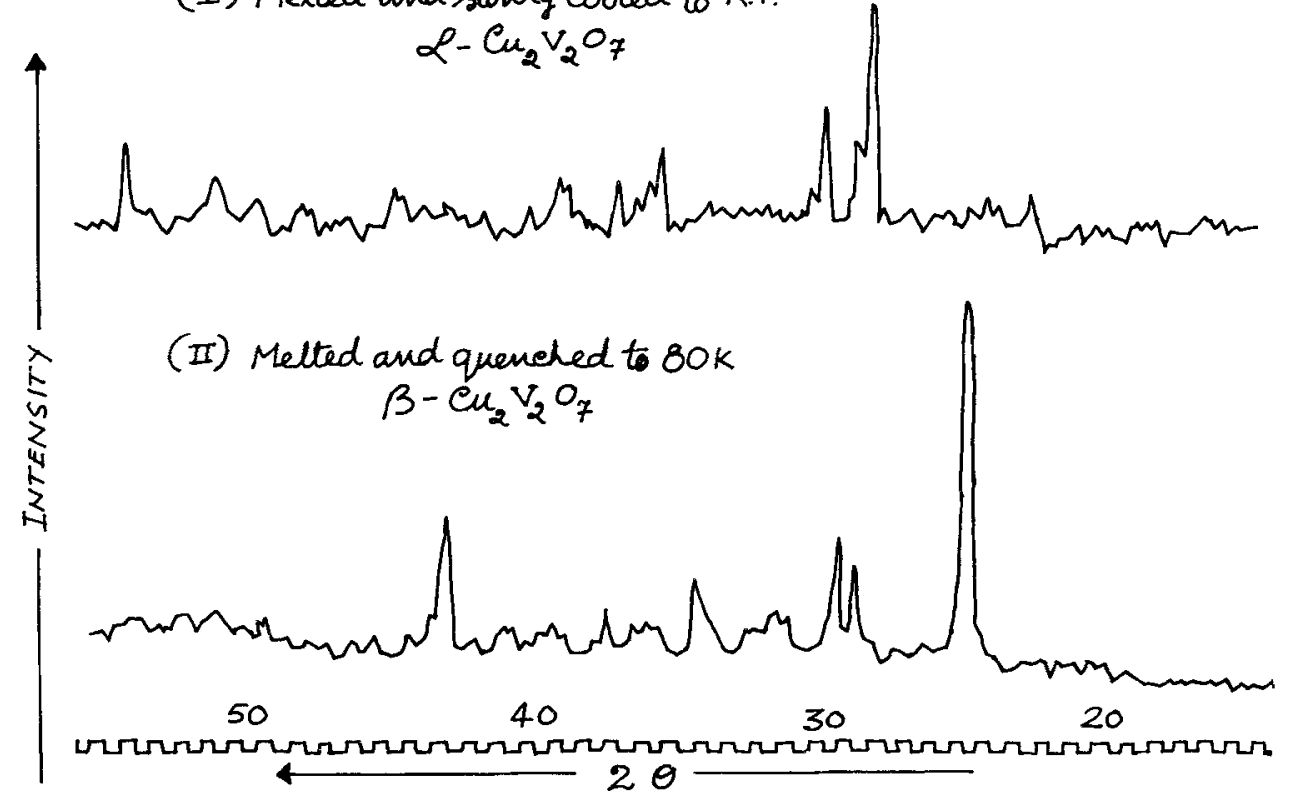

Figure 3. XRD patterns of $\mathrm{Cu}_{2} \mathrm{~V}_{2} \mathrm{O}_{7}$ samples (I) and (II).

proper nucleation and growth of the phase during heating and cooling cycles. A representative portion of the high temperature XRD of this sample I that was recorded at $25^{\circ} \mathrm{C}, 478^{\circ} \mathrm{C}$ and $528^{\circ} \mathrm{C}$ is shown in figure 4 . The XRD patterns clearly showed phase transformations at high temperature. The XRD reflections recorded during the cooling cycle of $\mathrm{Cu}_{2} \mathrm{~V}_{2} \mathrm{O}_{7}$ also confirmed the reversibility of the phases. These observations (both DTA and XRD) were in contrast to the $\alpha \rightarrow \beta$ transformation observed at $712^{\circ} \mathrm{C}$ by Fluery et al (1969) where $\beta \rightarrow \alpha$ transition was sluggish.

As is evident from figure 4 the XRD reflections of $\mathrm{Cu}_{2} \mathrm{~V}_{2} \mathrm{O}_{7}$ (sample I) at $3.26 \AA$ was the strongest at $25^{\circ} \mathrm{C}$ and fell gradually in intensity with temperature and disappeared altogether above $478^{\circ} \mathrm{C}$. Curiously enough, the same reflection (d:3.27 $\AA$ ) appeared above $525^{\circ} \mathrm{C}$. The decreasing intensity of reflection at $3 \cdot 27 \AA$ was accompanied by the growth characteristic of $\beta-\mathrm{Cu}_{2} \mathrm{~V}_{2} \mathrm{O}_{7}$ phase (i.e. $3.60 \AA, 3.09 \AA$, $3.06 \AA$ etc). It was noticed that when the $\beta-\mathrm{Cu}_{2} \mathrm{~V}_{2} \mathrm{O}_{7}$ was heated to a temperature above $525^{\circ} \mathrm{C}$ the strongest reflection was observed $(3.60 \AA)$ and few others disappeared. The entire XRD data obtained above $525^{\circ} \mathrm{C}$ was similar to the XRD data $\alpha-\mathrm{Cu}_{2} \mathrm{~V}_{2} \mathrm{O}_{7}$ taken at $25^{\circ} \mathrm{C}$. This points out that the phase existing above $525^{\circ} \mathrm{C}$ is also isostructural to $\alpha-\mathrm{Cu}_{2} \mathrm{~V}_{2} \mathrm{O}_{7}$ (or a closely related thortveitite structure, figure 1). Thus high temperature XRD confirmed and corroborated our DTA results.

The DTA and XRD of $\mathrm{Cu}_{2} \mathrm{~V}_{2} \mathrm{O}_{7}$ (sample I) can be summarized as below:

$$
\alpha-\mathrm{Cu}_{2} \mathrm{~V}_{2} \mathrm{O}_{7} \underset{435^{\circ} \mathrm{C}}{\stackrel{475^{\circ} \mathrm{C}}{\rightleftharpoons}} \beta-\mathrm{Cu}_{2} \mathrm{~V}_{2} \mathrm{O}_{7} \underset{485^{\circ} \mathrm{C}}{\stackrel{500^{\circ} \mathrm{C}}{\rightleftharpoons}} \alpha-\mathrm{Cu}_{2} \mathrm{~V}_{2} \mathrm{O}_{7}
$$

All the three phases of $\mathrm{Cu}_{2} \mathrm{~V}_{2} \mathrm{O}_{7}$ were identified, characterized and indexed. The XRD data of these crystal phases are given in table 1.

The room temperature phase of $\mathrm{Cu}_{2} \mathrm{~V}_{2} \mathrm{O}_{7}$ is identified as $\alpha-\mathrm{Cu}_{2} \mathrm{~V}_{2} \mathrm{O}_{7}$ which is 


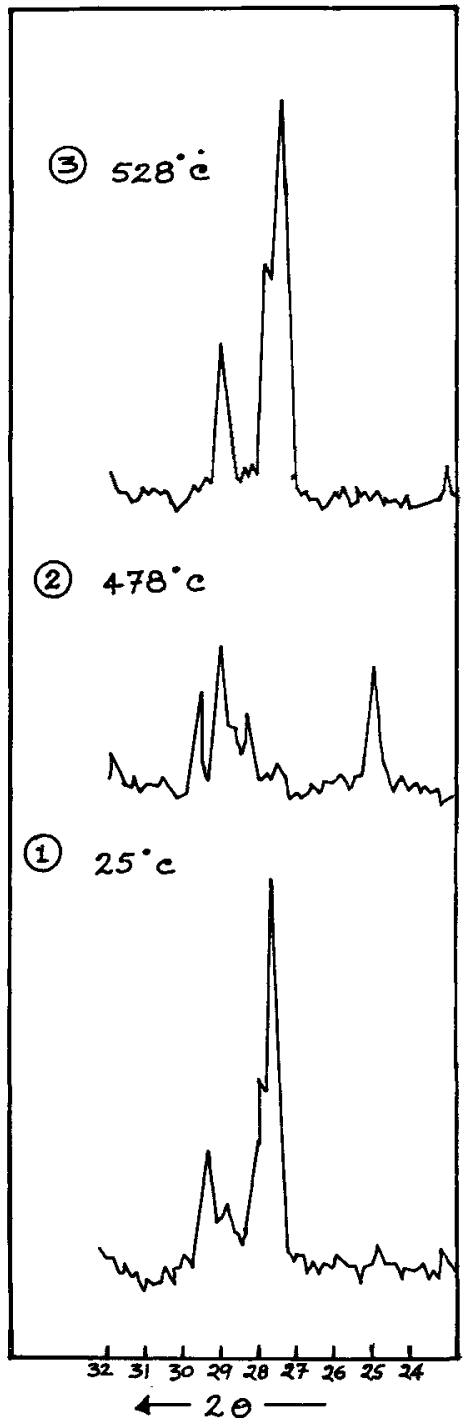

Figure 4. XRD for $\mathrm{Cu}_{2} \mathrm{~V}_{2} \mathrm{O}_{7}$ at $25^{\circ} \mathrm{C}(1), 478^{\circ} \mathrm{C}(2)$ and $528^{\circ} \mathrm{C}(3)$ respectively.

isotypic to the phase reported by Mercurio et al (1973a) and Calvo and Faggiani (1975). This $\alpha-\mathrm{Cu}_{2} \mathrm{~V}_{2} \mathrm{O}_{7}$ has crystal symmetry orthorhombic $\mathrm{Fdd2}$; while the $\beta-\mathrm{Cu}_{2} \mathrm{~V}_{2} \mathrm{O}_{7}$ phase observed at $478^{\circ} \mathrm{C}$ is also isostructural to the phase reported by Mercurio et al (1973b) with crystal symmetry monoclinic $\mathrm{C} 2 / \mathrm{c}$. In contrast, Ayamonino et al (1972) and Fluery et al (1969) reported a different $\mathrm{Cu}_{2} \mathrm{~V}_{2} \mathrm{O}_{7}$ phase with thortveitite structure with the crystal symmetry monoclinic $\mathrm{C} 2 / \mathrm{m}$ (which they obtained only on heating $2 \mathrm{CuO}: \mathrm{V}_{2} \mathrm{O}_{5}$ at $600^{\circ} \mathrm{C}$ for $80 \mathrm{~h}$ in air). Interestingly, the $\beta-\mathrm{Cu}_{2} \mathrm{~V}_{2} \mathrm{O}_{7}$ phase is unstable above $525^{\circ} \mathrm{C}$ and reverts to $\alpha-\mathrm{Cu}_{2} \mathrm{~V}_{2} \mathrm{O}_{7}$ structure. Since this high temperature $\mathrm{Cu}_{2} \mathrm{~V}_{2} \mathrm{O}_{7}$ phase is isotypic to $\alpha-\mathrm{Cu}_{2} \mathrm{~V}_{2} \mathrm{O}_{7}$, the crystal symmetry of this high temperature phase is orthorhombic Fdd2 (or a closely related structure). 
Table 1. XRD data for $\mathrm{Cu}_{2} \mathrm{~V}_{2} \mathrm{O}_{7}$ at $25^{\circ} \mathrm{C}, 478^{\circ} \mathrm{C}$ and $528^{\circ} \mathrm{C}$.

\begin{tabular}{|c|c|c|c|c|c|c|c|c|}
\hline \multicolumn{3}{|c|}{$\alpha-\mathrm{Cu}_{2} \mathrm{~V}_{2} \mathrm{O}_{7}$ at $25^{\circ} \mathrm{C}$} & \multicolumn{3}{|c|}{$\beta-\mathrm{Cu}_{2} \mathrm{~V}_{2} \mathrm{O}_{7}$ at $478^{\circ} \mathrm{C}$} & \multicolumn{3}{|c|}{$\alpha-\mathrm{Cu}_{2} \mathrm{~V}_{2} \mathrm{O}_{7}$ at $528^{\circ} \mathrm{C}$} \\
\hline $\mathrm{d} \AA_{\text {obs }}$ & $I / I_{0}$ & $h k l$ & $\mathrm{~d} \AA_{\text {obs }}$ & $I / I_{0}$ & $h k l$ & $d \AA_{\text {obs }}$ & $I / I_{0}$ & $h k l$ \\
\hline $5 \cdot 170$ & 10 & 400 & $5 \cdot 340$ & 15 & 110 & $5 \cdot 160$ & 15 & 400 \\
\hline 4.970 & 8 & 111 & 4200 & 15 & 111 & 4.970 & 8 & 111 \\
\hline $4 \cdot 100$ & 15 & 311 & $4 \cdot 100$ & 10 & 112 & $4 \cdot 100$ & 20 & 311 \\
\hline 3.896 & 8 & 220 & 3.980 & 15 & 020 & 3.890 & 15 & 220 \\
\hline $3 \cdot 266$ & 100 & 420 & 3.680 & 5 & 027 & 3.250 & 100 & 420 \\
\hline 3.225 & 30 & 511 & 3.600 & 100 & 200 & $3 \cdot 210$ & 70 & 511 \\
\hline 3.070 & 40 & 202 & $3 \cdot 160$ & 40 & 112 & 3.070 & 45 & 202 \\
\hline 3.050 & 40 & - & 3.090 & 100 & 113 & 3.040 & 10 & - \\
\hline 2.585 & 15 & 800 & 3.040 & 75 & 022 & 2.580 & 20 & 800 \\
\hline $2 \cdot 560$ & 20 & 022 & $2 \cdot 771$ & 10 & 221 & 2.558 & 25 & 022 \\
\hline 2.487 & 30 & 222 & 2.640 & 60 & 222 & 2.480 & 30 & 222 \\
\hline $2 \cdot 407$ & 10 & 331 & 2.490 & 10 & 131 & - & - & - \\
\hline $2 \cdot 354$ & 10 & 602 & $2 \cdot 460$ & 20 & 113 & - & - & - \\
\hline $2 \cdot 292$ & 10 & 422 & $2 \cdot 360$ & 5 & 004 & $2 \cdot 292$ & 15 & 422 \\
\hline $2 \cdot 203$ & 20 & 802 & $2 \cdot 350$ & 20 & 131 & $2 \cdot 203$ & 10 & 802 \\
\hline $2 \cdot 183$ & 25 & 521 & $2 \cdot 300$ & 15 & 310 & $2 \cdot 180$ & 10 & 531 \\
\hline $2 \cdot 102$ & 20 & 040 & $2 \cdot 111$ & 40 & 222 & 2.099 & 5 & 040 \\
\hline 2.096 & 20 & 911 & 2.080 & 45 & 133 & 2.090 & 30 & 911 \\
\hline - & - & - & 2057 & 30 & 224 & $2 \cdot 072$ & 20 & 113 \\
\hline 2.054 & 30 & 622 & 1.950 & 20 & 041 & 2.048 & 20 & 622 \\
\hline 1.945 & 6 & 440 & 1.850 & 15 & 133 & 1.945 & 20 & 440 \\
\hline- & - & - & 1.824 & 5 & 223 & 1.940 & 10 & 731 \\
\hline- & - & - & 1.778 & 20 & 225 & 1.734 & 10 & 242 \\
\hline $1 \cdot 712$ & 30 & 931 & 1.693 & 10 & 423 & 1.710 & 40 & 931 \\
\hline $1 \cdot 700$ & 20 & 133 & 1.674 & 10 & 206 & 1.700 & 20 & 133 \\
\hline 1.631 & 10 & 840 & 1.606 & 15 & 135 & 1.630 & 30 & 840 \\
\hline 1.611 & 20 & 004 & 1.564 & 10 & 150 & 1.611 & 20 & 004 \\
\hline 1.576 & 15 & 533 & 1.560 & 10 & 151 & - & - & - \\
\hline
\end{tabular}

These structures can be considered as members of the thortveitite type with nearly staggered $\left(\mathrm{V}_{2} \mathrm{O}_{7}\right)^{4-}$ groups. These pyrovanadate groups lie in paralleled sheets bonded by $\mathrm{Cu}^{2+}\left(\mathrm{d}^{9}\right)$ cation. Each copper atom is surrounded by five oxygen atoms forming a distorted trigonal bipyramid.

It is remarkable that when $\mathrm{Cu}_{2} \mathrm{~V}_{2} \mathrm{O}_{7}$ phase is melted and annealed (or quenched) oxygen vacancies or depletion of oxygen to a smaller extent could be expected in the copper-vanadium-oxygen lattice. On oxygen depletion either by annealing or by quenching from high temperatures, the linear chains may be disrupted and the oxygen atoms rearranged in the lattice. It was interesting to observe that the superconducting cuprate perovskites were found to be structurally sensitive to the oxygen content (Cava et al 1987; Jorgensen et al 1987). It was observed in $\mathrm{YBa}_{2} \mathrm{Cu}_{3} \mathrm{O}_{x}$ systems that the superconducting orthorhombic phase stabilized at room temperature for an oxygen content $6 \cdot 5<x<7$ (Jorgenson et al 1987). Below $x=6 \cdot 5$, the high temperature tetragonal semiconducting phase stabilized and the stabilities of such phases based on oxygen stoichiometry appeared to depend on the biography of the samples synthesized. Thus $\mathrm{Cu}_{2} \mathrm{~V}_{2} \mathrm{O}_{7}$ phase obtained was stabilized under the above conditions of preparation with a oxygen deficient lattice. $\mathrm{The}^{\mathrm{Cu}_{2}} \mathrm{~V}_{2} \mathrm{O}_{7}$ phase structure appeared 
to be sensitive and prone to transformation at high temperature due to $\mathrm{Cu}^{2+}\left(\mathrm{d}^{9}\right)$ in oxygen lattice and/or vacancy disordered oxygen lattice. $n$-Type semiconductivity was observed for $\mathrm{Cu}_{2} \mathrm{~V}_{2} \mathrm{O}_{7}$ (Palanna 1975) which confirmed the oxygen deficient lattice of $\mathrm{Cu}_{2} \mathrm{~V}_{2} \mathrm{O}_{7}$. But for this behaviour, $\mathrm{Cu}_{2} \mathrm{~V}_{2} \mathrm{O}_{7}$ phase would have been an insulator.

In conclusion, we would attribute that molten $\mathrm{Cu}_{2} \mathrm{~V}_{2} \mathrm{O}_{7}$ when annealed (or quenched) to room temperature has an oxygen deficient/vacancy disordered structure. This stabilized crystal structure at room temperature has XRD data similar to $\mathrm{Cu}_{2} \mathrm{~V}_{2} \mathrm{O}_{7}$ XRD of Riassento (1958) (ASTM card File No 16-417) obtained below the melting point of $\mathrm{Cu}_{2} \mathrm{~V}_{2} \mathrm{O}_{7}$. Both the samples obtained above and below the melting point $\left(780^{\circ} \mathrm{C}\right)$ of $\mathrm{Cu}_{2} \mathrm{~V}_{2} \mathrm{O}_{7}$ have identical XRD pattern indicating that they have the same basic structure; but as was evident from our investigation, the thermal behaviour (DTA) was different for the former exhibiting temperature phase transition and that too, at a temperature much lower than $712^{\circ} \mathrm{C}$ as reported earlier (Fluery et al 1969).

\section{Acknowledgements}

The authors sincerely thank UGC for providing the research grant for the investigation and express their gratitude to the Chemical Division, Bhabha Atomic Research Centre, Bombay for obtaining the high temperature XRD of the samples.

\section{References}

Angenault et al 1970 Rev.: Chim. Mineral 7651

Ayanomino et al 1973 Z. Kristallogr. 137221

Baglio J A and Dann J N 1972 J. Solid State Chem. 487

Calvo C and Au P K L 1967 Can. J. Chem. 452297

Calvo C and Faggiani R 1975 Acta Kristallogr. B31 603

Calvo C and Gopal R 1973 Can. J. Chém. 511004

Calvo C and Gopal R 1974 Acta. Kristallogr. B30 2491

Cava R J et al 1987 Nature (London) 329423

Cruickshank D W J et al 1962 Acta Kristallogr. 15491

Dorm E and Mariander B O 1967 Acta Chem. Scand. 21591

Fluery P et al 1969 Rev. Chim. Mineral 6819

Jorgensen J D et al 1987 Phys. Rev. B36 5731

Mercurio et al 1973a Acta Kristallogr. B29 2737

Mercurio et al 1973b C. R. Acad. Sci. Paris Ser. C277 1101

Monelescu D 1974 MSc. Thesis, McMaster Univ. Hamilton Ontario, Canada

Palanna O G 1975 Ph.D. Thesis, Indian Institute of Technology, Bombay

Riassento 1958 Ann. Chim. (Rom) 48263

Sauerbrei E E et al 1974 Acta Kristallogr. B30 2907

Sauerbrei E E and Faggiani R 1975 Acta Kristallogr. B31 603

Ziolkowski J and Deimbaj L 1978 Mater. Chem. 3157 